\title{
SEXUALITY AND DEMOCRACY
}


to my mother and sisters,

whose lives and experiences thank

fully made me wonder (as only women can)

about whether I should ever become

(what is supposedly)

a real man. 


\title{
SEXUALITY AND DEMOCRACY \\ Identities and Strategies in Lesbian and Gay Politics
}

\author{
Momin Rahman
}


(C) Momin Rahman, 2000

Transferred to Digital Print 2010

Edinburgh University Press Ltd

22 George Square, Edinburgh

Typeset in Palatino Light

by Pioneer Associates, Perthshire, and

Printed and bound in Great Britain by

CPI Antony Rowe, Chippenham and Eastbourne

A CIP record for this book is available from the British Library

ISBN $074860958 \times$ (paperback)

ISBN 9781474471855 (EPDF)

The right of Momin Rahman

to be identified as author of this work

has been asserted in accordance with

the Copyright, Designs and Patents Act 1988. 